\title{
Isolation, enumeration, molecular identification and probiotic potential evaluation of lactic acid bacteria isolated from sheep milk
}

\author{
[Isolamento, enumeração, identificação molecular e avaliação do potencial probiótico de \\ bactérias ácido-lácticas do leite de ovelha] \\ L.B. Acurcio ${ }^{1}$, M.R. Souza ${ }^{1}$, A.C. Nunes ${ }^{2}$, D.L.S. Oliveira ${ }^{1}$, S.H.C. Sandes ${ }^{2}$, L.B. Alvim ${ }^{2}$ \\ ${ }^{1}$ Escola de Veterinária - Universidade Federal de Minas Gerais - EV-UFMG - Belo Horizonte, MG \\ ${ }^{2}$ Instituto de Ciências Biológicas - Universidade Federal de Minas Gerais - ICB-UFMG- Belo Horizonte, MG
}

\section{RESUMO}

Espécies de bactérias ácido-lácticas foram identificadas em nível molecular em leite das raças ovinas Lacaune, Santa Inês e suas mestiças, e o seu potencial probiótico in vitro foi avaliado. As espécies identificadas foram Enterococcus faecium (56,25\%), E. durans (31,25\%) e E. casseliflavus (12,5\%). Nenhuma outra espécie de bactéria ácido-láctica, como Lactobacillus sp., foi identificada. A maioria dos enterococos isolados foi resistente ao $\mathrm{pH}$ gástrico (2.0) e a $0,3 \%$ de oxgall. Todos os enterococos testados foram resistentes à ceftazidima, oxacilina e estreptomicina e sensíveis à clindamicina, eritromicina $\mathrm{e}$ penicilina. A resistência à ciprofloxacina, gentamicina, tetraciclina e vancomicina variou entre as amostras. Todos os enterococos testados inibiram fortemente $(\mathrm{P}<0,05)$ Escherichia coli e Listeria monocytogenes, inibiram moderadamente E. faecalis e Staphylococcus aureus e não inibiram Pseudomonas aeruginosa, Salmonella enterica var. Typhimurium e uma amostra de E. durans isolada de leite de ovelha. Quatro amostras de E. faecium, uma de E. durans e uma de E. casseliflavus apresentaram o melhor potencial probiótico.

Palavras-chave: leite de ovelha, enterococos, potencial probiótico

\begin{abstract}
Lactic acid bacteria species were molecularly identified in milk from Lacaune, Santa Inês and crossbred sheep breeds and their in vitro probiotic potential was evaluated. The species identified were Enterococcus faecium (56.25\%), E. durans (31.25\%) and E. casseliflavus (12.5\%). No other lactic acid bacteria species, such as lactobacilli, was identified. Most of the isolated enterococci were resistant to gastric $\mathrm{pH}(2.0)$ and to $0.3 \%$ oxgall. All tested enterococci were resistant to ceftazidime, oxacillin and streptomycin and sensible to clindamycin, erythromycin and penicillin. The resistance to ciprofloxacin, gentamicin, tetracycline and vancomycin varied among tested species. All tested enterococci strongly inhibited $(P<0.05)$ Escherichia coli and Listeria monocytogenes, moderately inhibited $\mathrm{E}$. faecalis and Staphylococcus aureus and did not inhibit Pseudomonas aeruginosa, Salmonella enterica var. Typhimurium and also one E. durans sample isolated from sheep milk. Four samples of $\mathrm{E}$. faecium, one of E. durans and one of $\mathrm{E}$. casseliflavus presented the best probiotic potential.
\end{abstract}

Keywords: sheep milk, enterococci, probiotic potential

\section{INTRODUCTION}

Sheep milk represents only $1.3 \%$ of total global milk production, but is mostly used for cheese making, such as Roquefort, Pecorino and Serra da Estrela, with a better yield and higher value-

Recebido em 5 de junho de 2012

Aceito em 7 de novembro de 2013

E-mail: leonaruto@hotmail.com added since its solids ratio is higher than other ruminant milks (Tsakalidou and Odos, 2012).

It is important to determine the sheep milk microbiota in order to understand the transformations that occur in cheese through its maturation. Studies from Abeijón et al. (2006) 
and Madrau et al. (2006) found predominance of the Enterococcus genus in sheep milk and determined their role in proteolysis during cheese maturation. Despite of that, there is not a focus on the probiotic potential of these microorganisms, such as their ability to resist gastric acid and biliary salts in order to reach their final destination - small or large intestine in viable counts, and their antagonistic potential against important pathogenic microorganisms in the gastrointestinal tract (Silva et al., 2013). It is also important to evaluate antimicrobial susceptibility regarding probiotic properties because of the possible transference of antimicrobial resistance to pathogenic microorganisms from probiotic microorganisms (Lund and Edlund, 2001). Probiotic products are mainly represented by dairy products such as yogurts and fermented milks (Maragkoudakis et al., 2006).

Thus, the objective of this study was to determine the probiotic potential of microorganisms isolated from sheep milk for possible future use as probiotics in several dairies improving flavor and safety.

\section{MATERIAL AND METHODS}

Sheep milk was obtained at a small farm situated near Jaboticatubas city, Minas Gerais state, Brazil. Twenty samples were obtained from Lacaune, Santa Inês (a Brazilian breed) and their crossbreds. Dilutions were made up to $10^{-5}$ and were spread into Petri dishes containing MRS (Man Rogosa and Sharpe, Difco, USA) agar incubated for $96 \mathrm{~h}$ at $37^{\circ} \mathrm{C}$ - and M17 (Difco) agar - incubated for $96 \mathrm{~h}$ at $32^{\circ} \mathrm{C}$. Enumeration was made in Petri dishes containing from 20 to 200 CFU. Morphologically distinct colonies were submitted to Gram test, and the ones that had rod or round shape and were Gram positive were selected for further identification (adapted from IDF, 1983).

DNA from selected cultures was first obtained through treatment with $\mathrm{LiCl}(1 \mathrm{M})$ for pellets obtained from each activated culture.Then they were incubated at $37^{\circ} \mathrm{C}$ with constant mixing for $1 \mathrm{~h}$. New pellets were obtained and suspended in $1 \mathrm{~mL}$ of protoplast buffer $(50 \mathrm{mM}$ Tris $\mathrm{HCl} \mathrm{pH}$ $8.0 ; 10 \mathrm{mM}$ EDTA and $10 \mathrm{mg}$ de lysozyme $\mathrm{mL}^{-1}$ ) with incubation at $37^{\circ} \mathrm{C}$ with constant mixing for 1h. Total DNA was finally obtained with Wizard
SV Genomic and DNA Purification System (Promega, USA), following the manufacturer indication.

All DNA samples were submitted to PCR reaction according to Tisala-Timisjarvi and Alatossava (1997). Primer 27F (5' AGAGTTtGATCCTGGCTCAG 3') was used as forward and 1492R (5' GGTTACCTTGTTACGACTT 3') as reverse to amplify the $16 \mathrm{~S}$ rDNA gene of each sample. The program used was: $95^{\circ} \mathrm{C}$ for the first $150 \mathrm{sec}, 35$ cycles of $94^{\circ} \mathrm{C}$ for $30 \mathrm{sec}, 55^{\circ} \mathrm{C}$ for $60 \mathrm{sec}, 72^{\circ} \mathrm{C}$ for $60 \mathrm{sec}$ and finally $72^{\circ} \mathrm{C}$ for $10 \mathrm{~min}$, according to Moreira et al. (2005). Each sample was purified by Wizard SV Gel and PCR Clean-up System (Promega), according the manufacturer's instructions.

Each 16S rDNA sample was sequenced through Sanger's method with MegaBace 1000 (GE HealthCare, UK) according to Reysenbach et al. (2000). Results were submitted to the BLAST algorithm from GenBank located on the NCBI website.

Selected microorganisms were activated twice $24 \mathrm{~h}$ at $37^{\circ} \mathrm{C}-$ in $5 \mathrm{~mL}$ of broth similar to the original solid medium that they grew in. Each sample was incubated at $37^{\circ} \mathrm{C}$ in the presence of gastric juice $(0.85 \% \mathrm{NaCl}, \mathrm{pH} 2.0)$ for $3 \mathrm{~h}$ and distributed $(2 \% \mathrm{v} / \mathrm{v})$ in three wells in a 96-well ELISA plate containing $0.2 \mathrm{~mL}$ of pure MRS (Difco) broth each. The control of each sample was done with incubation at $37^{0} \mathrm{C}$ for $3 \mathrm{~h}$ in the presence of saline $(0.85 \% \mathrm{NaCl}) \mathrm{pH} 7.0$. They were alsodistributed $(2 \% \mathrm{v} / \mathrm{v})$ in three other wells containing $0.2 \mathrm{~mL}$ of pure MRS broth each. Each plate containing 15 samples was incubated at $37^{\circ} \mathrm{C}$ for $18 \mathrm{~h}$. Absorbance at $620_{\mathrm{nm}}$ was read every 30min on a Spectramax 340 spectrophotometer (Molecular Devices, USA). Using Origin 8.5 (OriginLab, USA), differences in growth curve areas for each sample - control and in the presence of gastric juice - were calculated and the percentage of in vitro inhibition by gastric juice was obtained. This procedure was adapted from Walker and Gilliland (1993). Two repetitions were made.

Selected microorganisms were activated two times $\left(24 \mathrm{~h}\right.$ at $\left.37^{\circ} \mathrm{C}\right)$ in $5 \mathrm{~mL}$ of the broth similar to the original solid medium that they grew in. 
Each sample was distributed $(2 \% \mathrm{v} / \mathrm{v})$ in three wells in a 96-well ELISA plate containing $0.2 \mathrm{~mL}$ of pure MRS (Difco) broth each, and in three wells containing $0.2 \mathrm{mLof}$ MRS (Difco) broth with $0.3 \%$ oxgall (Difco) each. Each plate containing 15 samples was incubated at $37^{\circ} \mathrm{C}$ for $18 \mathrm{~h}$. Absorbance at $620_{\mathrm{nm}}$ was read every $30 \mathrm{~min}$ on a Spectramax 340 spectrophotometer (Molecular Devices). Using Origin 8.5 (OriginLab), differences in growth curve areas for each sample (control and in the presence of $0.3 \%$ oxgall - Difco) were calculated and the percentage of in vitro inhibition by biliary salts was obtained (adapted from Walker and Gilliland, 1993). Two repetitions were made.

Selected microorganisms were activated once $24 \mathrm{~h}$ at $37^{\circ} \mathrm{C}-$ in $5 \mathrm{~mL}$ of brothand then in agar similar to the original solid medium that they grew in. Then, each microorganism was transferred to $3.5 \mathrm{~mL}$ of saline $(0.85 \% \mathrm{NaCl})$ until turbidity equal to 0.5 on McFarland scale was obtained. Using a swab, each microorganism was transferred to a Petri dish containing MRS (Difco) agar. Antimicrobial discs (Oxoid, UK) were equally distributed on the surface of the agar. The antimicrobials used were: penicillin (PEN, 10U), oxacillin (OX, 1 $\mu \mathrm{g})$, vancomycin

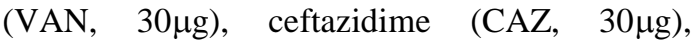

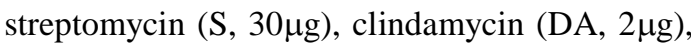
erythromycin (E, $5 \mu \mathrm{g})$, ciprofloxacin (CIP, $5 \mu \mathrm{g}$ ), gentamicin $(\mathrm{CN}, 10 \mu \mathrm{g})$, and tetracycline (TE, $30 \mu \mathrm{g})$. Each dish was incubated at $37^{\circ} \mathrm{C}$ for $48 \mathrm{~h}$. Quality control was done using Escherichia coli ATCC 25922. The inhibition halos were measured with a Mitutoyo digital paquimeter (Mitutoyo, Brazil). This procedure was executed in duplicate with three repetitions and was adapted from Charteris (1998).

Selected microorganisms were activated twice $24 \mathrm{~h}$ at $37^{\circ} \mathrm{C}-$ in $5 \mathrm{~mL}$ of broth similar to the agar that they originally grew in. A $5 \mu \mathrm{L}$ spot was made from each activated microorganism in the center of a Petri dish containing MRS (Difco) agar. Each Petri dish was incubated for $48 \mathrm{~h}$ at $37^{\circ} \mathrm{C}$. Then, $1 \mathrm{~mL}$ of chloroform was added to the cover of each Petri dish and left to rest for $30 \mathrm{~min}$ under UV. Another 30min with the cover open were needed to evaporate the chloroform. The revealing microorganisms were then added onto the surface of the former dishes through $7.5 \mu \mathrm{L}$ of their recent culture in $3.5 \mathrm{~mL}$ of semi-solid $\mathrm{BHI}$ (Difco) for Enterococcus faecalis ATCC 19433, Escherichia coli ATCC 25922, Listeria monocytogenes ATCC 15313, Pseudomonas aeruginosa ATCC 28853, Salmonella enterica var. Typhimurium ATTCC 14028 and Staphylococcus aureus ATCC 29213; or semisolid MRS (Difco) agar for Enterococcus durans sample 23 isolated from sheep milk in the present study. Each dish was incubated for $48 \mathrm{~h}$ at $37^{\circ} \mathrm{C}$. The inhibition halos of each microorganism against the revealing microorganisms were measured with a Mitutoyo digital paquimeter (Mitutoyo). This procedure was executed in duplicate with three repetitions and was adapted from Tagg et al. (1976). The data obtained was analyzed using the KruskalWallis test, since results from this kind of test usually present an abnormal behavior, and the level of significance was set at $\mathrm{P}<0.05$.

\section{RESULTS AND DISCUSSION}

Using Sanger's method of sequencing the 16srDNA gene from microorganisms isolated from sheep milk, the following species were identified: nine $(56.25 \%)$ out of 16 identified species were Enterococcus faecium, five $(31.25 \%)$ were Enterococcus durans and two (12.5\%) were Enterococcus casseliflavus (Table 1).

Medina et al. (2001), when identifying microorganisms isolated from sheep milk, also found a high percentage $(48 \%)$ of bacteria from the Enterococcus genus. In a similar study, a lower $(33 \%)$, but also significant percentage of bacteria from the Enterococcus genus was found in sheep milk (Oksuztepe et al., 2005).

According to Gilliland et al. (1984), when a 0.3 absorbance is achieved after at least $2 \mathrm{~h}$ of incubation at $37^{\circ} \mathrm{C}$ in presence of gastric $\mathrm{pH}$ between 1.5 and 4.0, a microorganism can be considered tolerant or resistant to gastric $\mathrm{pH}$. Considering this, $13(81.25 \%)$ out of 16 samples tested can be considered tolerant to gastric $\mathrm{pH}$ (Table 2). 
Isolation, enumeration, molecular...

Table 1. Enterococcus spp. isolated from sheep milk identified by the sequencing of 16S rDNA gene using Sanger's method

\begin{tabular}{lll}
\hline Sheep (Breed) & Sample & Species \\
\hline 1433 (half-blood) & 3.1 & E. faecium \\
L04 (Lacaune) & 4.2 & E. faecium \\
1516 (half-blood) & 5 & E. durans \\
L09 (Lacaune) & 6.2 & E. faecium \\
L09 (Lacaune) & 6.4 & E. faecium \\
194 (half-blood) & 8.2 & E. durans \\
1448 (half-blood) & 10.3 & E. casseliflavus \\
81 (Santa Inês) & 12.1 & E. faecium \\
81 (Santa Inês) & 12.2 & E. faecium \\
102 (half-blood) & 14.1 & E. faecium \\
102 (half-blood) & 14.3 & E. casseliflavus \\
102 (half-blood) & 14.4 & E. faecium \\
1469 (half-blood) & 16 & E. durans \\
300 (half-blood) & 20.4 & E. durans \\
300 (half-blood) & 20.5 & E. faecium \\
1508 (half-blood) & 23 & E. durans \\
\hline
\end{tabular}

Table 2. Maximum absorbance achieved by enterococci samples isolated from sheep milk after $3 \mathrm{~h}$ incubation at $37^{\circ} \mathrm{C}$ in the presence of gastric $\mathrm{pH}(2.0)$ and subsequent $18 \mathrm{~h}$ incubation at $37^{\circ} \mathrm{C}$ in plain MRS broth

\begin{tabular}{|c|c|c|}
\hline Sheep (Breed) & Sample (Species) & Maximum Absorbance \\
\hline 81 (Santa Inês) & 12.1 (E. faecium) & 0.987 \\
\hline L09 (Lacaune) & 6.2 (E. faecium) & 0.986 \\
\hline 102 (half-blood) & 14.1 (E.faecium) & 0.966 \\
\hline 300 (half-blood) & 20.5 (E.faecium) & 0.945 \\
\hline 81 (Santa Inês) & 12.2 (E.faecium) & 0.944 \\
\hline 300 (half-blood) & 20.4 (E. durans) & 0.933 \\
\hline 1469 (half-blood) & 16 (E. durans) & 0.891 \\
\hline 1516 (half-blood) & 5 (E. durans) & 0.699 \\
\hline 102 (half-blood) & 14.3 (E. casseliflavus) & 0.493 \\
\hline L09 (Lacaune) & 6.4 (E. faecium) & 0.366 \\
\hline 1433 (half-blood) & 3.1 (E. faecium) & 0.938 \\
\hline 102 (half-blood) & 14.4 (E. faecium) & 0.324 \\
\hline L04 (Lacaune) & 4.2 (E. faecium) & 0.320 \\
\hline 194 (half-blood) & 8.2 (E. durans) & 0.261 \\
\hline 1448 (half-blood) & 10.3 (E. casseliflavus) & 0.223 \\
\hline 1508 (half-blood) & 23 (E. durans) & 0.166 \\
\hline
\end{tabular}

Morandi et al. (2005) found tolerance to acid $\mathrm{pH}$ from E. faecium samples such as what was found in the present work.

Tolerance to gastric juice was also considered for samples that achieved less than $40 \%$ of inhibition, therefore, 12 (75\%) out of 16 samples were considered tolerant (Tab. 3). Sample 10.3 was not considered tolerant because it did not achieve a 0.3 absorbance (Table2).

In a similar study, a $38.5 \%$ inhibition by gastric juice from $E$. durans and $56.8 \%$ from $E$. faecium samples were observed, confirming the resistance to gastric $\mathrm{pH}$ by enterococci samples observed in the present study (Cueto-Vigil et al., 2010). 
Table 3. Inhibition percentage by gastric $\mathrm{pH}$ (2.0) of 16 enterococcisamples isolated from sheep milk

\begin{tabular}{|c|c|c|}
\hline Sheep (Breed) & Sample (Species) & Inhibition (\%) \\
\hline 81 (Santa Inês) & 12.1 (E. faecium) & 0.00 \\
\hline 102 (half-blood) & 14.1 (E. faecium) & 0.00 \\
\hline 300 (half-blood) & 20.4 (E. durans) & 0.73 \\
\hline 300 (half-blood) & 20.5 (E. faecium) & 2.08 \\
\hline 81 (Santa Inês) & 12.2 (E. faecium) & 5.66 \\
\hline 1469 (half-blood) & 16 (E. durans) & 7.26 \\
\hline L09 (Lacaune) & 6.4 (E.faecium) & 16.01 \\
\hline L04 (Lacaune) & 4.2 (E. faecium) & 19.74 \\
\hline 1433 (half-blood) & 3.1 (E. faecium) & 26.29 \\
\hline 1448 (half-blood) & 10.3 (E. casseliflavus) & 26.75 \\
\hline L09 (Lacaune) & 6.2 (E. faecium) & 31.97 \\
\hline 1516 (half-blood) & 5 (E. durans) & 36.00 \\
\hline 102 (half-blood) & 14.3 (E. casseliflavus) & 39.60 \\
\hline 194 (half-blood) & 8.2 (E. durans) & 42.42 \\
\hline 102 (half-blood) & 14.4 (E. faecium) & 57.62 \\
\hline 1508 (half-blood) & 23 (E. durans) & 75.28 \\
\hline
\end{tabular}

According to Gilliland et al. (1984), when 0.3 of absorbance is achieved after at least $8 \mathrm{~h}$ of incubation at $37^{\circ} \mathrm{C}$ in presence of $0.3 \%$ oxgall, a microorganism can be considered tolerant or resistant to biliary salts. Considering this, 11 $(68.75 \%)$ out of 16 samples tested can be considered tolerant to biliary salts (Table 4).

Table 4. Maximum absorbance achieved by enterococci samples isolated from sheep milk after $18 \mathrm{~h}$ incubation at $37^{\circ} \mathrm{C}$ in presence of $0.3 \%$ of oxgall

\begin{tabular}{|c|c|c|}
\hline Sheep (Breed) & Sample (Species) & Maximum Absorbance \\
\hline 1433 (half-blood) & 3.1 (E. faecium) & 0.938 \\
\hline 1516 (half-blood) & 5 (E. durans) & 0.883 \\
\hline 194 (half-blood) & $8.2($ E. durans $)$ & 0.843 \\
\hline L09 (Lacaune) & 6.4 (E. faecium) & 0.841 \\
\hline 1469 (half-blood) & 16 (E. durans) & 0.841 \\
\hline L04 (Lacaune) & 4.2 (E. faecium) & 0.834 \\
\hline L09 (Lacaune) & $6.2($ E. faecium $)$ & 0.827 \\
\hline 102 (half-blood) & 14.4 (E. faecium) & 0.824 \\
\hline 1508 (half-blood) & 23 (E. durans) & 0.799 \\
\hline 102 (half-blood) & 14.3 (E. casseliflavus) & 0.768 \\
\hline 300 (half-blood) & 20.5 (E.faecium) & 0.576 \\
\hline 102 (half-blood) & 14.1 (E.faecium) & 0.245 \\
\hline 81 (Santa Inês) & $12.2($ E.faecium $)$ & 0.225 \\
\hline 81 (Santa Inês) & 12.1 (E. faecium) & 0.213 \\
\hline 300 (half-blood) & 20.4 (E. durans) & 0.132 \\
\hline 1448 (half-blood) & 10.3 (E. casseliflavus) & 0.039 \\
\hline
\end{tabular}

Tolerance to $1 \%$ oxgall from $E$. durans and $E$. faecium samples isolated from Feta cheese was observed in another study (Ambadoyiannis et al., 2005). Pereira and Gibson (2002) found tolerance to $0.4 \%$ oxgall from an E. durans sample.
Tolerance to biliary salt was also considered for samples that achieved less than $40 \%$ of inhibition, therefore, nine $(56.25 \%)$ out of 16 samples were considered tolerant to biliary salts (Table 5). Sample 14.1 was not considered tolerant because it did not achieve a 0.3 absorbance (Table 4). 
Isolation, enumeration, molecular...

Table 5. Inhibition percentage by biliary salts (oxgall $0.3 \%$ ) of 16 enterococci samples isolated from sheep milk

\begin{tabular}{|c|c|c|}
\hline Sheep (Breed) & Sample (Species) & Inhibition (\%) \\
\hline 1433 (half-blood) & 3.1 (E. faecium) & 23.22 \\
\hline 102 (half-blood) & 14.3 (E. casseliflavus) & 26.68 \\
\hline 1516 (half-blood) & $5($ E. durans $)$ & 26.69 \\
\hline 194 (half-blood) & $8.2($ E. durans $)$ & 26.89 \\
\hline 102 (half-blood) & 14.4 (E. faecium) & 27.51 \\
\hline L04 (Lacaune) & $4.2($ E. faecium $)$ & 30.14 \\
\hline 1508 (half-blood) & 23 (E. durans) & 31.76 \\
\hline L09 (Lacaune) & $6.2($ E. faecium $)$ & 32.55 \\
\hline L09 (Lacaune) & 6.4 (E.faecium) & 32.75 \\
\hline 102 (half-blood) & 14.1 (E. faecium) & 34.14 \\
\hline 1469 (half-blood) & $16($ E. durans $)$ & 41.64 \\
\hline 300 (half-blood) & 20.5 (E. faecium) & 44.27 \\
\hline 81 (Santa Inês) & 12.2 (E. faecium) & 58.76 \\
\hline 81 (Santa Inês) & 12.1 (E. faecium) & 58.76 \\
\hline 300 (half-blood) & 20.4 (E. durans) & 63.01 \\
\hline 1448 (half-blood) & 10.3 (E. casseliflavus) & 85.88 \\
\hline
\end{tabular}

All enterococci samples were resistant to ceftazidime, oxacillin and streptomycin; and sensitive to clindamycin (sample 12.1 was only moderately sensitive), erythromycin, penicillin and tetracycline (sample 20.4 was only moderately sensitive). Samples 12.1 and 14.1 were the only ones moderately sensible to ciprofloxacin and sensitive to vancomycin, and the other samples were resistant. These two samples were also the only ones resistant to tetracycline, and the others were sensitive. Samples 14.4 and 20.5 were the only ones sensitive to gentamicin, and the other samples were resistant (Table 6).

Table 6. Enterococci antimicrobial susceptibility ${ }^{\mathrm{a}}$

\begin{tabular}{|c|c|c|c|c|c|c|c|c|c|c|}
\hline \multirow{2}{*}{ Sample } & \multicolumn{10}{|c|}{ Antimicrobial } \\
\hline & CAZ & CIP & $\mathrm{DA}$ & $E$ & GN & $\mathrm{OX}$ & $\mathrm{P}$ & $\mathrm{S}$ & $\mathrm{TE}$ & VA \\
\hline 3.1 & $\mathrm{R}$ & $\mathrm{R}$ & $\mathrm{S}$ & $\mathrm{S}$ & $\mathrm{R}$ & $\mathrm{R}$ & $\mathrm{S}$ & $\mathrm{R}$ & $\mathrm{S}$ & $\mathrm{R}$ \\
\hline 4.2 & $\mathrm{R}$ & $\mathrm{R}$ & $\mathrm{S}$ & $\mathrm{S}$ & $\mathrm{R}$ & $\mathrm{R}$ & S & $\mathrm{R}$ & $\mathrm{S}$ & $\mathrm{R}$ \\
\hline 5 & $\mathrm{R}$ & $\mathrm{R}$ & $\mathrm{S}$ & $\mathrm{S}$ & $\mathrm{R}$ & $\mathrm{R}$ & $\mathrm{S}$ & $\mathrm{R}$ & $S$ & $\mathrm{R}$ \\
\hline 6.2 & $\mathrm{R}$ & $\mathrm{R}$ & $\mathrm{S}$ & $\mathrm{S}$ & $\mathrm{R}$ & $\mathrm{R}$ & $\mathrm{S}$ & $\mathrm{R}$ & S & $\mathrm{R}$ \\
\hline 6.4 & $\mathrm{R}$ & $\mathrm{R}$ & $\mathrm{S}$ & $\mathrm{S}$ & $\mathrm{R}$ & $\mathrm{R}$ & $\mathrm{S}$ & $\mathrm{R}$ & S & $\mathrm{R}$ \\
\hline 8.2 & $\mathrm{R}$ & $\mathrm{R}$ & $\mathrm{S}$ & $\mathrm{S}$ & $\mathrm{R}$ & $\mathrm{R}$ & $\mathrm{S}$ & $\mathrm{R}$ & $\mathrm{S}$ & $\mathrm{R}$ \\
\hline 10.3 & $\mathrm{R}$ & $\mathrm{R}$ & $\mathrm{S}$ & $\mathrm{S}$ & $\mathrm{R}$ & $\mathrm{R}$ & $\mathrm{S}$ & $\mathrm{R}$ & $S$ & $\mathrm{R}$ \\
\hline 12.1 & $\mathrm{R}$ & MS & MS & $\mathrm{S}$ & $\mathrm{R}$ & $\mathrm{R}$ & $\mathrm{S}$ & $\mathrm{R}$ & $\mathrm{R}$ & S \\
\hline 12.2 & $\mathrm{R}$ & $\mathrm{R}$ & $\mathrm{S}$ & $\mathrm{S}$ & $\mathrm{R}$ & $\mathrm{R}$ & $\mathrm{S}$ & $\mathrm{R}$ & $S$ & $\mathrm{R}$ \\
\hline 14.1 & $\mathrm{R}$ & MS & $\mathrm{S}$ & $\mathrm{S}$ & $\mathrm{R}$ & $\mathrm{R}$ & $\mathrm{S}$ & $\mathrm{R}$ & $\mathrm{R}$ & S \\
\hline 14.3 & $\mathrm{R}$ & $\mathrm{R}$ & $\mathrm{S}$ & $\mathrm{S}$ & $\mathrm{R}$ & $\mathrm{R}$ & $\mathrm{S}$ & $\mathrm{R}$ & $S$ & $\mathrm{R}$ \\
\hline 14.4 & $\mathrm{R}$ & $\mathrm{R}$ & $\mathrm{S}$ & $\mathrm{S}$ & $\mathrm{S}$ & $\mathrm{R}$ & $\mathrm{S}$ & $\mathrm{R}$ & $S$ & $\mathrm{R}$ \\
\hline 16 & $\mathrm{R}$ & $\mathrm{R}$ & $\mathrm{S}$ & $\mathrm{S}$ & $\mathrm{R}$ & $\mathrm{R}$ & $\mathrm{S}$ & $\mathrm{R}$ & S & $\mathrm{R}$ \\
\hline 20.4 & $\mathrm{R}$ & $\mathrm{R}$ & $S$ & $\mathrm{~S}$ & $\mathrm{R}$ & $\mathrm{R}$ & $\mathrm{S}$ & $\mathrm{R}$ & MS & $\mathrm{R}$ \\
\hline 20.5 & $\mathrm{R}$ & $\mathrm{R}$ & $\mathrm{S}$ & $\mathrm{S}$ & $\mathrm{S}$ & $\mathrm{R}$ & $\mathrm{S}$ & $\mathrm{R}$ & $S$ & $\mathrm{R}$ \\
\hline 23 & $\mathrm{R}$ & $\mathrm{R}$ & $\mathrm{S}$ & $\mathrm{S}$ & $\mathrm{R}$ & $\mathrm{R}$ & $\mathrm{S}$ & $\mathrm{R}$ & $\mathrm{S}$ & $\mathrm{R}$ \\
\hline
\end{tabular}

${ }^{\mathrm{a}}$ CAZ: ceftazidime $(30 \mu \mathrm{g}), \mathrm{CIP}$ : ciprofloxacin $(5 \mu \mathrm{g})$, DA: clindamycin $(2 \mu \mathrm{g})$, E: erythromycin $(5 \mu \mathrm{g})$, $\mathrm{GN}$ : gentamicin $(10 \mu \mathrm{g})$, OX: oxacillin $(1 \mu \mathrm{g})$, PEN: penicillin $(10 \mathrm{U})$, S: streptomycin $(30 \mu \mathrm{g})$, tetracycline $(30 \mu \mathrm{g})$, and vancomycin (VAN, $30 \mu \mathrm{g})$. R: resistant, MS: moderately sensible, S: sensible. 
Resistance to ciprofloxacin and vancomycin was found by most of the enterococci samples tested in a similar study (Coque et al., 1996), corroborating the findings of the present study. Cueto-Vigil et al. (2010) found sensitivity to clindamycin, erythromycin, penicillin and tetracycline by most of enterococci samples isolated from cheese, such as the enterococci isolated from sheep milk in this work.

Mannu et al. (2003), when comparing susceptibility to antimicrobials of enterococci from different origins, found that enterococci from raw sheep milk were sensitive to penicillin, tetracycline and vancomycin, and the ones isolated from sheep feces were sensitive to vancomycin, moderately sensitive to tetracycline and resistant to penicillin. This work leads to the supposition that the enterococci isolated from sheep milk in this study are from milk and not from feces - or any other contamination.

The inhibition of tested enterococci were considered significant $(\mathrm{P}<0.05)$ against $E$. coli and L. monocytogenes when compared to the other revealing microorganisms tested. The inhibition was less intense, but still significant $(\mathrm{P}<0.05)$, against $E$. faecalis and $S$. aureus when compared to the poor inhibition against $S$. Typhimurium, and the non-existent inhibition against $P$. aerugionosa and E. durans - sample 23 isolated from sheep milk (Table 7). It is interesting to notice here that an E. faecalis pathogenic sample was significantly $(\mathrm{P}<0.05)$ inhibited while an E. durans sample from sheep milk was not. None of the enterococci samples showed statistical difference in their behavior against all pathogens, indicating similar inhibition profiles according to Kruskal-Wallis test $(\mathrm{P}>0.05)$.

A diversity of bacteriocins produced by enterococci is known as good inhibitors to $L$. monocytogenes and $S$. aureus growth, according to Giraffa (1995). In Ennahar et al. (2001) and Sarantinopoulos et al. (2002) studies in different cheeses, different $E$. faecium samples inhibited reference $L$. monocytogenes and $S$. aureus samples. These results confirm the results observed in the present study.
A study developed with enterococci from goat cheese against reference pathogens found, as in this work, inhibition against $E$. coli, $L$. monocytogenes and S. aureus (Psoni et al., 2006).

In Strompfová et al. (2006) and Taras et al. (2006) works, in vivo inhibition of different $E$. faecium probiotic samples against $E$. coli in piglets were proven. These results confirm what was demonstrated in vitro in the present work.

Table 7. Means ( $\mathrm{mm}$ ) of inhibition halos of enterococci samples against reference microorganisms $^{\mathrm{a}}$

\begin{tabular}{lc}
\hline Reference Microorganism & $\begin{array}{c}\text { Mean (mm) halo } \\
\text { Inhibition }\end{array}$ \\
\hline Escherichia coli & $65.60 \mathrm{a}$ \\
Listeria monocytogenes & $57.87 \mathrm{a}$ \\
Enterococcus faecalis & $24.11 \mathrm{~b}$ \\
Staphylococcus aureus & $19.84 \mathrm{~b}$ \\
Salmonella Typhimurium & $3.85 \mathrm{c}$ \\
Pseudomonas aeruginosa & $0.00 \mathrm{~d}$ \\
Enterococcus & $0.00 \mathrm{~d}$ \\
durans(sample 23) & \\
\hline
\end{tabular}

${ }^{a}$ Means followed by distinct letters are different by Kruskal-Wallis test $(\mathrm{p}<0.05)$

\section{CONCLUSION}

E. durans, E. faecium and E. casseliflavus samples isolated from sheep milk (from Lacaune, Santa Inês and their crossbreeds) can present in vitro probiotic properties such as resistance to gastric juice, biliary salts and antagonism against reference pathogens such as Escherichia coli, Listeria monocytogenes and Staphylococcus aureus. Therefore, their use as probiotics in dairy products is promising, although more in vitro and in vivo studies are needed to prove their full probiotic potential and their inability to transfer antimicrobial resistance genes.

\section{ACKNOWLEDGMENTS}

We thank FAPEMIG (Fundação de Amparo à Pesquisa em Minas Gerais) for the funding and LGMPP at ICB UFMG and DTIPOA at EV UFMG laboratories for the equipment and help provided. 


\section{REFERENCES}

ABEIJÓN, M.C.; MEDINA, R.B.; KATZ, M.B. Technological properties of Enterococcus faecium isolated from ewe's milk and cheese with importance for flavor development. Can. J. Microbiol., v.52, p.237-245, 2006.

AMBADOYIANNIS, G.; HATZIKAMARI, M.; LITOPOULOU-TZANETAKI, E. et al. Probiotic and technological properties of Enterococci isolates from infants and cheese. Food Biotechnol., v.18, p.307-325, 2005.

CHARTERIS, A. Antibiotic susceptibility of potentially probiotic Lactobacillus species. J. Food Protect., v.61, p.1636-1643,1998.

COQUE, M.T.; TOAMYKO, J.F.; RICKE, S.C. et al. Vancomycin-resistant enterococci from nosocomial, community, and animal sources in the United States. Antimic. Ag.Chemoter., v.40, p.2605-2609, 1996.

CUETO-VIGIL, M.C.; ACUNÃ-MONSALVE, Y.; VALENZUELA-RIAÑO, J. Evaluación in vitro del potencial probiótico de bactérias ácido lácticas aisladas del suero costeño. Actual. Biol., v.32, p.129-138, 2010.

ENNAHAR, S.; ASOU, Y.; ZENDO, T. et al. Biochemical and genetic evidence for production of enterocins A and B by Enterococcus faecium WHE 81. International J. Food Microbiol., v.70, p.291-301, 2001.

GILLILAND, S.E.; STALEY, T.E.; BUSH, L.J. Importance of bile tolerance of Lactobacillus acidophilus used as a dietary adjunct. J. Dairy Sci., v.67, p.3045-3051, 1984.

GIRAFFA, G. Enterococcal bacteriocins - their potential as anti-Listeria factors in dairy technology. Food Microbiol., v.12, p.291-299, 1995.

IDF, International Dairy Federation. Yogurt: enumeration of characteristic microorganisms count technique at $37^{\circ} \mathrm{C}$. Bul. of the Internat. Dairy Fede., v.117, p.1-4, 1983.

LUND, B.; EDLUND, C. Probiotic Enterococcus faecium strain is a possible recipient of the vanA gene cluster. Clin. Infect. Dis., v.32, p.1384$1385,2001$.
MADRAU, M.A.; MANGIA, N.P.; MURGIA, M.A. et al. Employment of autochthonous microflora in Pecorino Sardo cheese manufacturing and evolution of physicochemical parameters during ripening. Int. Dairy J., v.16, p.876-885, 2006.

MANNU, L.; PABA, A.; DAGA, E. et al. Comparison of the incidence of virulence determinants and antibiotic resistance between Enterococcus faecium strains of dairy, animal and clinical origin. Int. J. Food Microbiol., v.88, p.291-304, 2003.

MARAGKOUDAKIS, P.A.; ZOUMPOPOULOU, G.; MIARIS, C. et al. Probiotic potential of Lactobacillus strains isolated from dairy products. Int. Dairy J., v.16, p.189-199, 2006.

MORANDI, S.; BRASCA, M.; ALFIERI, P. et al. Influence of $\mathrm{pH}$ and temperature on the growth of Enterococcus faecium and Enterococcus faecalis. Lait, v.85, p.181-192, 2005.

MOREIRA, J.L.S.; MOTA, R.M.; HORTA, M.F. et al. Identification to the species level of Lactobacillus isolated in probiotic prospecting studies of human, animal or food origin by $16 \mathrm{~S}$ 23S rRNA restriction profiling. BMC Microbiol., v.5, p.1-10, 2005.

MEDINA, R.; KATZ, M.; GONZALEZ, S. et al. Characterization of the lactic acid bacteria in ewe's milk and cheese from Northwest Argentina. J. Food Protect., v.64, p.559-563, 2001.

OKSUZTEPE, G.; PATIR, B.; ÇALICIOGLU, M. Identification and distribution of lactic acid bacteria during the ripening of savatulum cheese. Turk. J. Vet. Anim. Sci., v.29, p.873-978, 2005

PEREIRA, D.I.A.; GIBSON, G.R. Cholesterol assimilation by lactic acid bacteria and bifidobacteria isolated from the human gut. Appl. Environ. Microbiol., v.68, p.4689-4693, 2002.

PSONI, L.; KOTZAMANIDES, C.; ANDRIGHETTO, C. et al. Genotypic and phenotypic heterogeneity in Enterococcus isolates from Batzos, a raw goat milk cheese. Int. J. Food Microbiol., v.109, p.109-120, 2006. 
REYSENBACH， A.L.; LONGNECKER， K.; KIRSHTEIN, J. Novel bacterial and archael lineages from an in situ growth chamber deployed at a mid-atlantic ridge hydrothermal vent. Appl. Environ. Microbiol., v.66, p.37983806, 2000.

SARANTINOPOULOS, P.; KALANTZOUPOULOS, G.; TSAKALIDOU, E. Effect of Enterococcus faecium on microbiological, physicochemical and sensory characteristics of greek feta cheese. Int. J. Food Microbiol., v.76, p.93-105, 2002.

SILVA, B.C.; JUNG, L.R.; SANDES, S.C. et al. In vitro assessment of functional properties of lactic acid bacteria isolated from faecal microbiota of healthy dogs for potential use as probiotics. Benef. Microbes, v.4, p.267-275, 2013.

STROMPFOVÁ, V.; MARCINAKOVÁ, M.; SIMONOVÁ, M. et al. Enterococcus faecium EK13 - an enterocin A - producing strain with probiotic character and its effect in piglets. Anaerobe, v.12, p.242-248, 2006.
TARAS, D.; VAHJEN, W.; MACHA, M. et al. Performance, diarrhea incidence, and occurrence of Escherichia coli virulence genes during longterm administration of a probiotic Enterococcus faecium strain to sows and piglets. J. Anim. Sci., v.84, p.608-617, 2006.

TAGG, J.R.; DAJANI, A.S.; WANNAMAKER, L.W. Bacteriocin of Gram positive bacteria. Bact. Rev., v.40, p.722-756, 1976.

TISALA-TIMISJARVI, A.; ALATOSSAVA, T. Development of oligonucleotide primers from the 16S-23S rDNA intergenic sequences for identifying different dairy and probiotic lactic acid bacteria by PCR. Int. J. Food Microbiol., v.35, p.49-56, 1997.

TSAKALIDOU, E; ODOS, I. Microbiota of Goat's Milk and Goat's Milk Cheese. In: ASIA DAIRY GOAT CONFERENCE, 1., 2012, Kuala Lumpur. Proceedings... Kuala Lumpur: [s.n] 2012, p.40-41. (Expanded abstract).

WALKER, D.K.; GILLILAND, S.E. Relationships among bile tolerance, bile salt desconjugation, and assimilation of cholesterol by Lactobacillus acidophilus. J. Dairy Sci., v.76, p.956-961, 1993. 